\title{
STRATEGI PENGELOLAAN ASET TETAP PADA PEMERINTAH PROVINSI BANTEN
}

\author{
Fixed Asset Management Strategies in the Government of Banten Province
}

\author{
Een Mulyani ${ }^{1}$, Dwi Rachmina ${ }^{2}$, Nunung Kusnadi ${ }^{2}$
}

${ }^{1}$ Auditor Badan Pengawasan Keuangan dan Pembangunan. Email: een.mulyani@gmail.com

${ }^{2}$ Staff Pengajar Departemen Agribisnis. Fakultas Ekonomi dan Manajemen IPB. Email: dwirachmina@yahoo.com, nunungkusnadi@yahoo.com

\begin{abstract}
The Government of Banten Province during the years 2011-2014 has not received an Unqualified Opinion (WTP) of The Supreme Audit Agency (BPK) in its financial statements. The opinion had been given by BPK during the years of 2011-2012 is The Qualified Opinion (WDP). The opinion for years of 2013-2014 is Disclaimer Opinion (TMP).The key to giving WDP and TMP, among others, for the presentation of assets are considered not meet the principles of fairness appropriate presentation of The Government Accounting Standards (SAP). The research objective to describe fixed asset management system. The results of the performance of the system in the form of presentation of fixed assets. The next goal to identify internal and external factors affecting fixed asset management system. The ultimate destination for formulating strategies to improve management of fixed assets. The study was conducted in The Government of Banten Province, particularly the Bureau of Equipment and Assets (BPA) under the Regional Secretary and all work units (SKPD). Methods for assessing the performance of the presentation of fixed assets is Transformation Index. Identification of factors that affect the management of assets and formulate a strategy used SWOT Analysis Method. Methods of Analysis Hierarchy Process (AHP) to ge the priority of a strategy based on expert opinion. Conclusion the study shows the priority of asset management strategy is a strategy to improve the quality of data assets, strategy implementation Improvement Action Plan (RTP) and strategies for improving inter-agency cooperation. The formulation of the strategy is also supported by the proposed program of each strategy. The results of the study are expected to improve fixed asset management system and its implementation in The Government of Banten Province.
\end{abstract}

Key words: financial statement, fixed asset, strategy

\begin{abstract}
ABSTRAK
Pemerintah Provinsi Banten selama tahun 2011-2014 belum memperoleh opini Wajar Tanpa Pengecualian (WTP) dari Badan Pemeriksa Keuangan (BPK) pada laporan keuangannya. Opini yang diberikan oleh BPK untuk tahun 2011 dan 2012 adalah Wajar Dengan Pengecualian (WDP). Opini untuk tahun 2013 dan 2014 berupa Tidak Menyatakan Pendapat (TMP). Kunci dari pemberian opini WDP dan TMP antara lain karena penyajian aset tetap dianggap belum memenuhi prinsip kewajaran penyajian sesuai Standar Akuntansi Pemerintah (SAP). Tujuan penelitian ini adalah untuk mendeskripsikan sistem pengelolaan aset tetap. Hasil dari sistem berupa kinerja penyajian aset tetap. Tujuan berikutnya mengidentifikasi faktor internal dan eksternal yang mempengaruhi sistem pengelolaan aset tetap. Tujuan terakhir untuk merumuskan strategi perbaikan pengelolaan aset tetap. Penelitian dilakukan pada Pemerintah Provinsi Banten, khususnya Biro Perlengkapan dan Aset (BPA) di bawah Sekretaris Daerah beserta seluruh Satuan Kerja Perangkat Daerah (SKPD). Metode untuk menilai kinerja penyajian aset tetap adalah Transformasi Indek. Identifikasi faktor-faktor yang mempengaruhi pengelolaan aset dan merumuskan strategi digunakan Metode Analisis SWOT. Metode Analisis Hierarchy Process (AHP) membantu pemilihan prioritas strategi berdasarkan pendapat ahli. Kesimpulan penelitian menunjukkan prioritas strategi pengelolaan aset adalah strategi peningkatan kualitas aset data, strategi pelaksanaan Rencana Tindak Perbaikan (RTP)/action plan dan strategi peningkatan kerjasama antar lembaga. Perumusan strategi juga ditunjang dengan usulan kebijakan/program terhadap masing-masing strategi. Hasil dari penelitian diharapkan dapat memperbaiki sistem pengelolaan aset tetap dan pelaksanaannya di Pemerintah Provinsi Banten.
\end{abstract}




\section{PENDAHULUAN}

\section{Latar Belakang}

Salah satu upaya nyata untuk mewujudkan transparansi dan akuntabilitas pengelolaan keuangan negara adalah menyampaikan laporan pertanggung jawaban keuangan pemerintah yang memenuhi prinsip-prinsip akuntansi dan pelaporan keuangan pemerintah yang baik. Laporan pertanggungjawaban keuangan pemerintah disusun dengan mengacu pada Pernyataan Standar Akuntansi Pemerintah (PSAP) yang dikeluarkan oleh Komite Standar Akuntansi Pemerintahan (KSAP) yang telah diresmikan juga dalam Peraturan Pemerintah Nomor 71 Tahun 2010 tentang Standar Akuntansi Pemerintah.

Kualitas penyelenggaraan akuntansi keuangan dapat diukur melalui jenis opini atas laporan keuangan dari hasil audit yang dilakukan oleh auditor eksternal, baik BPK maupun Akuntan Publik. Opini auditor eksternal atas penyajian laporan keuangan secara bertingkat terdiri atas Tidak Memberikan Pendapat (TMP), Tidak Wajar (TW), Wajar Dengan Pengecualian (WDP), dan yang terbaik adalah Wajar Tanpa Pengecualian (WTP). Semakin baik opini atas suatu laporan keuangan menunjukkan semakin baiknya kualitas penyelenggaraan pengelolaan keuangan. Kualitas laporan keuangan merupakan salah satu indikator dalam mewujudkan good government dan clean governance. Ikhtisar Hasil Pemeriksaan BPK Semester I Tahun 2015 memuat perkembangan opini pada 34 LKPD tingkat provinsi Tahun 2014 ditampilkan pada Tabel 1.

Hal yang harus menjadi perhatian serius Pemerintah Provinsi Banten dari Tabel 1 di atas adalah bahwa Pemerintah Provinsi Banten merupakan satu-satunya pemerintah tingkat provinsi yang memperoleh opini TMP pada Tahun 2014 dari 34 provinsi yang ada di Indonesia.
Tabel 1. Opini BPK RI atas Laporan Keuangan Pemerintah Provinsi SeIndonesia Tahun 2011-2014

\begin{tabular}{|c|c|c|c|c|c|c|c|c|c|c|}
\hline \multirow{2}{*}{ Th } & \multicolumn{10}{|c|}{ Jenis Opini } \\
\hline & \multicolumn{2}{|c|}{ WTP } & \multicolumn{2}{|c|}{ WDP } & \multicolumn{2}{|c|}{ TW } & \multicolumn{2}{|c|}{ TMP } & \multicolumn{2}{|c|}{ Total } \\
\hline 20 & 1 & 30 & 1 & 58 & 0 & 0 & 4 & 12 & 3 & 100 \\
\hline $\begin{array}{l}11 \\
20\end{array}$ & $\hat{1}$ & 52 & $\stackrel{n}{1}$ & 33 & 0 & $\stackrel{0}{0}$ & 4 & $0 / 2$ & 3 & 100 \\
\hline 17 & 7 & & 1 & / & 0 & / & 5 & / & , & \\
\hline 20 & 1 & 48 & 1 & 45 & 0 & 0 & 2 & 6 & 3 & 100 \\
\hline 12 & G & $0 / \Omega$ & 5 & $0 / 2$ & & $0 / \Omega$ & & $0 / \pi$ & 2 & o/ \\
\hline 20 & 2 & 76 & 7 & 21 & 0 & 0 & 1 & 3 & 3 & 100 \\
\hline
\end{tabular}

semester I Tahun 2015

Selama empat tahun berturut-turut terjadi penurunan kualitas opini atas Laporan Keuangan Pemerintah Daerah (LKPD) Provinsi Banten. Berdasarkan hasil audit BPK, Tahun 2011-2012 diperoleh opini WDP dan selama Tahun 2013-2014 diperoleh opini TMP. Salah satu permasalahan yang menjadi kunci pemberian opini WDP dan TMP dari BPK adalah permasalahan pada penyajian aset tetap. Penyajian aset tetap dalam LKPD dianggap belum memenuhi kewajaran penyajian sesuai dengan Standar Akuntansi Pemerintah (SAP).

\section{Perumusan Masalah}

Seperti telah diuraikan dalam pendahuluan, salah satu penyebab belum diperolehnya opini WTP pada LKPD Tahun 2011-2014 adalah penyajian aset tetap pada laporan keuangan yang belum dapat memenuhi prinsip kewajaran penyajian. Permasalahan penyajian aset tetap antara lain sebagai berikut:

1. Pada aset Tanah terdapat permasalahan antara lain tidak jelasnya lokasi/alamat Tanah berada, luas yang tidak diketahui/tidak sesuai dengan dokumen pengadaan, Tanah yang belum bersertifikat atau masih bersertifikat atas nama pihak lain, Tanah dengan pencatatan ganda (double accounting) antara pemerintah provinsi dengan kabupaten/kota, Tanah dengan penguasaan dan pemanfaatan oleh pihak lain, tidak ada pengamanan fisik atas 
Tanah, Tanah yang belum dapat dijelaskan nilainya, dokumen kepemilikan yang tidak memiliki kekuatan hukum, kesalahan dalam pengklasifikasian aset antara aset Tanah dan Gedung/Bangunan.

2. Pada Gedung /Bangunan terdapat permasalahan antara lain letak/lokasi dan luas Gedung/Bangunan yang tidak diketahui, tidak adanya dokumen kepemilikan, Gedung/Bangunan yang digunakan oleh pihak lain, pencatatan ganda dan Gedung/Bangunan yang belum jelas keberadaannya namun telah tercatat dalam daftar aset dengan nomor registrasi.

Pemerintah Provinsi Banten perlu merumuskan strategi agar penyajian aset tetap dalam laporan keuangan dapat memenuhi prinsip kewajaran penyajian. Pertanyaan penelitian yang akan dicari jawabannya adalah bagaimana sistem pengelolaan aset tetap di Pemerintah Provinsi Banten? Faktor-faktor apa yang mempengaruhi kinerja pengelolaan aset tetap? Bagaimana strategi perbaikan sistem pengelolaan aset tetap?

\section{Tujuan Penelitian}

Tujuan dari penelitian ini adalah untuk:

1. Mendeskripsikan sistem pengelolaan aset tetap di Pemerintah Provinsi Banten.

2. Mengidentifikasi faktor-faktor yang mempengaruhi kinerja pengelolaan aset tetap.

3. Merumuskan strategi perbaikan sistem pengelolaan aset tetap.

\section{Ruang Lingkup Penelitian}

Penelitian ini membatasi pengelolaan aset hanya pada tahap inventarisasi dan legal audit dari lima tahapan manajemen aset menurut Siregar (2004), yaitu; inventarisasi aset, legal audit, penilaian aset, optimalisasi pemanfaatan aset serta pengawasan dan pengendalian dengan pengembangan sistem informasi manajemen aset. Tahapan inventarisasi berupa pemenuhan aset tetap terhadap aspek fisik dan yuridis, sedangkan tahap legal audit berupa identifikasi terhadap permasalahan aset yang timbul dan upaya penyelesaiannya. Ke dua tahapan pengelolaan aset menurut Siregar (2004) tersebut dalam pelaksanaannya di Pemerintah Banten tertuang dalam Peraturan Daerah Nomor 17 Tahun 2008 tentang Pengelolaan Barang Milik Daerah. Tahapan inventarisasi dan legal audit tersebut sesuai dengan tahapan penatausahaan, pemanfaatan dan pengamanan/pemeliharaan.

Sesuai dengan permasalahan pengelolaan aset yang dihadapi dalam tahapan seperti disebutkan di atas, maka solusi strategi yang akan dirumuskan dalam penelitian ini juga merupakan solusi atas permasalahan inventarisasi dan legal audit aset tetap.

\section{Tinjauan Pustaka}

Homer (2014) menganalisis tingkat arti penting pelaksanaan kegiatan inventarisasi dan legalisasi aset tetap dengan melihat tingkat arti pentingnya terhadap kinerja pemerintah daerah. Hubungan yang signifikan antara regulasi dengan kinerja pengelolaan aset telah dibahas Azhar et al. (2011) dalam penelitiannya terhadap manajemen aset pada SKPD di Pemerintah Kota Banda Aceh. Pekei et al. (2013) membahas hubungan antara kualitas SDM dengan kinerja pengelolaan aset di Kota Jayapura. Penelitian M.S. Abdelhamid et al. (2014) menyatakan pengelolaan aset harus dilakukan berbeda sesuai tahapan kehidupan aset, yaitu perencanaan, pengadaan, operasi dan pemeliharaan, serta pembuangan.

\section{Kerangka Pemikiran}

Kerangka pemikiran diawali dengan mendeskripsikan sistem pengelolaan aset tetap pada Pemerintah Provinsi Banten. Sistem pengelolaan aset tetap berpengaruh dalam capaian kinerja aset tetap, terutama dalam kewajaran penyajian AT di laporan keuangan. Capaian kinerja penyajian aset tetap dapat dilihat dari kelengkapan aspek 
fisik, aspek yuridis dan aspek legal audit. Kondisi faktor lingkungan eksternal dan internal diteliti untuk melihat pengaruhnya pada pengelolaan aset tetap. Analisis terhadap faktor lingkungan menjadi dasar perumusan strategi perbaikan sistem pengelolaan aset tetap. Strategi yang dirumuskan merupakan pilihan yang diperingkatkan berdasar prioritas untuk diterapkan dan didahulukan pelaksanaannya dibanding strategi yang lain. Simpulan dan saran atas penelitian merupakan tahapan akhir dari kerangka pemikiran ini, seperti terlihat pada Gambar 1.

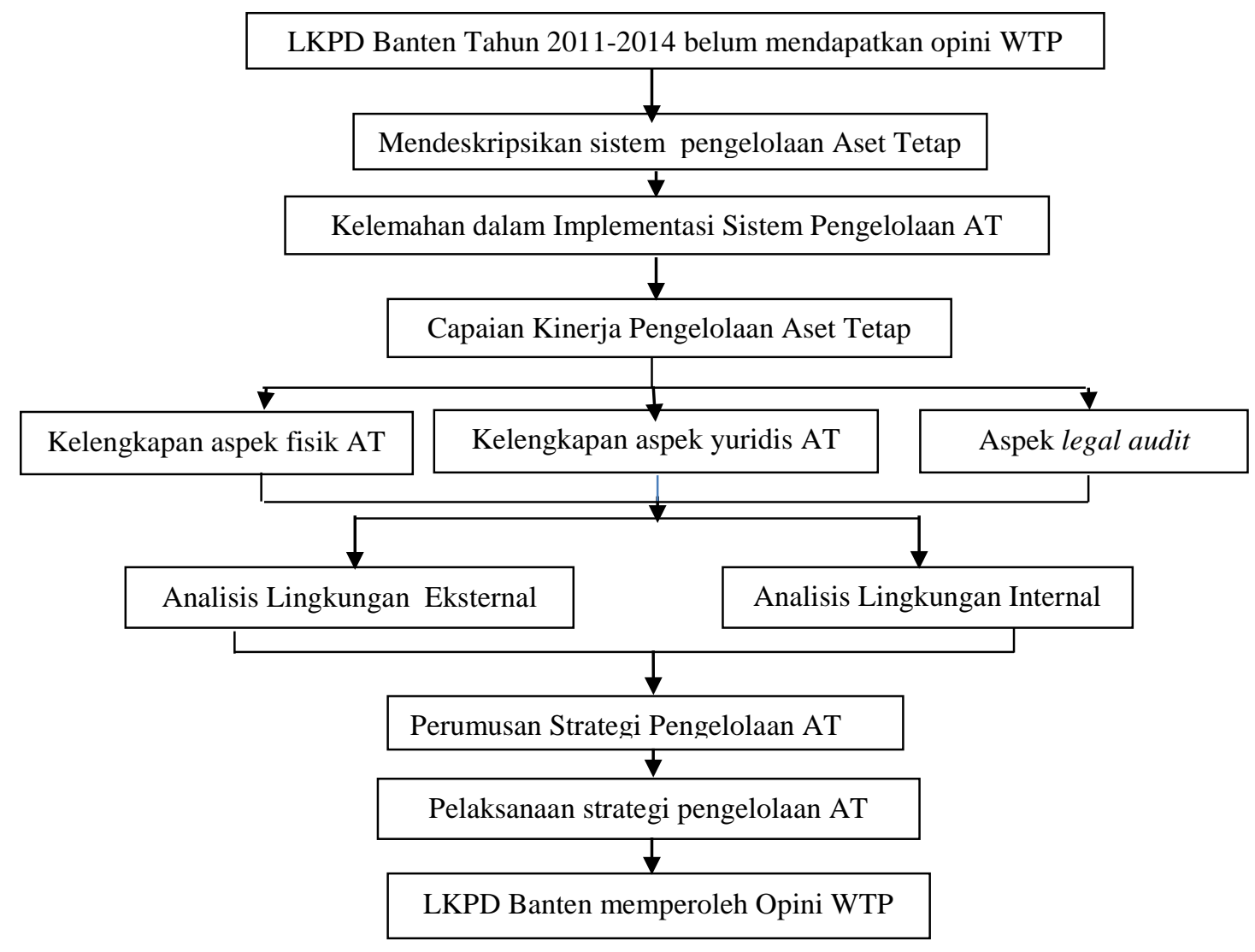

Gambar 1 Kerangka pemikiran

\section{METODE PENELITIAN}

\section{Lokasi dan Waktu Penelitian}

Penelitian dilakukan pada Biro Perlengkapan dan Aset (BPA) dan Satuan Kerja Perangkat Daerah (SKPD) di Pemerintah Provinsi Banten. BPA di bawah Sekretariat Daerah memiliki tugas pokok membantu Asisten Daerah Administrasi Umum melaksanakan pengelolaan kekayaan daerah. Waktu penelitian dilaksanakan selama tiga bulan sejak Januari sampai dengan Maret 2016.

\section{Jenis dan Teknik Pengumpulan Data}

Data yang digunakan dalam penelitian ini adalah data primer dan data sekunder. Data primer diperoleh dari Biro Perlengkapan dan Aset (BPA) berupa data aset dan peraturan daerah mau pun peraturan gubernur terkait pengelolaan aset. Data sekunder diperoleh berupa regulasi serta dokumen dari pemerintah pusat mau pun Laporan Hasil Audit BPK atas LKPD Pemerintah Provinsi Banten Tahun 2011-2014.

Teknik pengumpulan data dengan cara wawancara (indepth-interview) dan 
penyebaran kuesioner kepada pihak yang berkaitan langsung dengan pengelolaan aset daerah.

\section{Variabel Penelitian}

Variabel dalam tahapan inventarisasi dianalisis untuk menilai kinerja pemerintah daerah dalam pemenuhan aspek fisik dan yuridis sebuah aset tetap. Variabel lain yang turut mengukur kinerja tersebut adalah variabel dalam kegiatan legal audit. Masing-masing variabel tersebut adalah:

1. Kelengkapan aspek fisik tanah terdiri dari luas, letak/alamat dan bentuk penggunaan. Kelengkapan aspek yuridis terdiri dari status tanah (hak, nomor dan tanggal sertifikat), asal-usul, harga dan tahun pengadaan.

2. Kelengkapan aspek fisik gedung/bangunan terdiri dari kondisi, konstruksi (bertingkat/tidak, beton/tidak), luas lantai, letak/lokasi, luas dan nomor kode tanah. Aspek yuridis gedung/bangunan terdiri dari dokumen (tanggal dan nomor), status tanah, asal usul dan harga.

3. Aspek legal audit terdiri dari "permasalahan yang dihadapi" dan "upaya penyelesaiannya” yang telah dilakukan.

Variabel penelitian untuk Metode SWOT berupa faktor internal dan eksternal yang mempengaruhi pengelolaan aset di Pemerintah Provinsi Banten.

\section{Metode Pengolahan dan Analisis Data}

Metode Transformasi Indek adalah metode yang dipakai untuk menjawab tujuan pertama penelitian. Metode ini menilai kinerja Pemerintah Provinsi Banten dalam pemenuhan aspek fisik, yuridis dan legal audit pada aset tetap. Tujuan kedua penelitian dijawab dengan Metode Analisis SWOT dengan Matrik IFAS dan EFAS. Tujuan terakhir penelitian berupa perumusan strategi perbaikan pelaksanaan pengelolaan aset menggunakan Metode SWOT dengan Matrik Internal Eksternal dan Matrik SWOT. Metode Analytical Hierarchy Process (AHP) juga membantu perumusan strategi dengan melihat prioritas permasalahan menurut persepsi para ahli pengelolaan aset daerah.

\section{HASIL DAN PEMBAHASAN}

\section{Sistem Pengelolaan Aset Tetap}

Sistem Pengelolaan Aset Daerah berpedoman pada Peraturan Daerah Nomor 17 Tahun 2008 yang merupakan turunan dari Peraturan Menteri Dalam Negeri Nomor 17 Tahun 2007 tentang Pedoman Teknis Pengelolaan Barang Milik Daerah. Perda tersebut antara lain mengatur tentang kewenangan dan struktur pengelola aset daerah. Wewenang pengelolaan ada pada Sekretaris Daerah dibantu oleh Kepala Biro Perlengkapan dan Aset (BPA) sebagai pembantu pengelola BMD, dan Kepala SKPD sebagai pengguna barang dengan membawahi pengurus dan penyimpan barang. Namun dalam pelaksanaannya, masih terdapat fungsi pengelolaan yang tidak dilakukan atau tidak sesuai dengan ketentuan. Kelemahan tersebut antara lain berupa kurangnya koordinasi antara BPA dengan Kepala SKPD dalam penentuan kebutuhan akan SDM pengurus barang, kurangnya koordinasi antara BPA dengan Inspektorat dalam tindak lanjut temuan BPK, tidak adanya monitoring pelaksanaan pekerjaan oleh Kepala SKPD kepada stafnya, dan kurang optimalnya kegiatan pengelolaan seperti sensus BMD, rekonsiliasi data atau sosialisasi sistem dan kebijakan.

Sistem pengelolaan aset merupakan sistem yang terus dikembangkan menjadi lebih baik. Beberapa kelemahan dari sistem ini antara lain sistem belum memfasilitasi pola mutasi pengurus/penyimpan barang berdasarkan kebutuhan kompetensi di masing-masing SKPD, belum ada pola rekrutmen untuk pengurus/penyimpan barang, belum ada pola pendidikan dan pelatihan (diklat) yang baku bagi pengurus/penyimpan barang, kurangnnya perhatian terhadap kesejahteraan dan beban kerja pengurus barang dan belum memasukkan peran Inspektorat dalam sistem pengelolaan aset. 
Inspektorat hanya berperan secara rutin sebagai satuan pengendalian intern, yang pengawasannya bersifat umum kepada seluruh SKPD.

Sistem teknologi informasi pengelolaan aset menggunakan Sistem Informasi Managemen Daerah-Barang Milik Daerah (SIMDA BMD). Dalam implementasinya sering kali terkendala pada kompetensi SDM yang belum menjalankan fungsinya, seperti tidak dilakukannya input data secara rutin, kesalahan dalam proses input dan tidak adanya validasi atas proses input oleh atasan langsung.

Suatu sistem yang telah dirancang dengan sempurna, namun pelaksanaannya tidak sesuai ketentuan, dikhawatirkan tidak dapat mencapai kondisi yang diharapkan. Hal ini disebabkan kinerja merupakan hasil dari sistem yang berlaku dan diterapkan dalam sebuah organisasi.

\section{Kinerja Pengelolaan Aset Tetap}

Aset pemerintah daerah harus memenuhi ketentuan aspek fisik, yuridis dan legal audit (Siregar, 2004). Capaian kinerja aspek fisik, yuridis dan legal audit untuk tanah dan gedung/bangunan diperoleh dengan membandingkan kondisi yang ada dengan kondisi ideal. Kondisi ideal adalah nilai maksimum yang diperoleh jika suatu aset dapat memenuhi seluruh ketentuan dalam masing-masing aspek.

Aset tanah telah cukup memenuhi kriteria kelengkapan aspek fisik yang terdiri dari luas, letak/alamat dan bentuk fisik penggunaan, namun kurang memenuhi kelengkapan aspek yuridis yang terdiri status (hak, nomor dan tanggal sertifikat), asal-usul, harga dan tahun pengadaan. Tanah juga cukup memenuhi kelengkapan aspek legal audit yaitu rendahnya tingkat permasalahan yang dihadapi dan telah dilakukan upaya penyelesaiannya oleh Pemerintah Provinsi Banten. Indek kinerja aset tanah terdapat pada Tabel 2.

Tabel 2 Indek kinerja aset tanah

\begin{tabular}{|c|c|c|c|c|c|c|c|c|c|}
\hline \multirow{2}{*}{ Tahun } & \multicolumn{3}{|c|}{$\begin{array}{c}\text { Indek Pemenuhan } \\
\text { Aspek Fisik }\end{array}$} & \multicolumn{3}{|c|}{$\begin{array}{c}\text { Indek Pemenuhan } \\
\text { Aspek Yuridis }\end{array}$} & \multicolumn{3}{|c|}{$\begin{array}{c}\text { Indek Pemenuhan Aspek } \\
\text { Legal Audit }\end{array}$} \\
\hline & Kondisi & Ideal & $\begin{array}{c}\text { Capaian } \\
(\%)\end{array}$ & Kondisi & Ideal & $\begin{array}{c}\text { Capaian } \\
(\%)\end{array}$ & Kondisi & Ideal & $\begin{array}{c}\text { Capaian } \\
(\%)\end{array}$ \\
\hline 2011 & 1038 & 1284 & 80.84 & 1745 & 2568 & 67.95 & 781 & 856 & 91.24 \\
\hline 2012 & 1049 & 1293 & 81.13 & 1757 & 2586 & 67.94 & 792 & 862 & 91.88 \\
\hline 2013 & 1090 & 1353 & 80.56 & 1849 & 2706 & 68.33 & 798 & 902 & 88.47 \\
\hline 2014 & 1093 & 1368 & 79.90 & 1861 & 2736 & 68.02 & 773 & 912 & 84.76 \\
\hline
\end{tabular}

Sumber: SIMDA BMD 2014 (diolah)

Aset Gedung/Bangunan kurang memenuhi kelengkapan aspek fisik yang terdiri dari kondisi, konstruksi (bertingkat/tidak, beton/tidak), luas lantai, letak/lokasi, luas, dan nomor kode tanah tempat berdiri. Gedung/Bangunan belum memenuhi kelengkapan aspek yuridis yang terdiri dari kelengkapan dokumen (tanggal dan nomor), status tanah, asal usul dan harga. Capaian aspek legal audit cukup memuaskan artinya variable 'permasalahan yang dihadapi' cukup rendah dan 'upaya penyelesaiannya' telah dilakukan dengan baik oleh Pemerintah Provinsi Banten. Kinerja pemenuhan aspek untuk aset tetap Gedung/Bangunan disajikan dalam Tabel 3. 
Tabel 3 Indek kinerja aset gedung/bangunan

\begin{tabular}{|c|c|c|c|c|c|c|c|c|c|}
\hline \multirow{2}{*}{ Tahun } & \multicolumn{3}{|c|}{$\begin{array}{l}\text { Indek Pemenuhan } \\
\text { Aspek Fisik }\end{array}$} & \multicolumn{3}{|c|}{$\begin{array}{l}\text { Indek Pemenuhan } \\
\text { Aspek Yuridis }\end{array}$} & \multicolumn{3}{|c|}{$\begin{array}{l}\text { Indek Pemenuhan } \\
\text { Aspek Legal Audit }\end{array}$} \\
\hline & Kondisi & Ideal & $\begin{array}{c}\text { Capaian } \\
(\%)\end{array}$ & Kondisi & Ideal & $\begin{array}{c}\text { Capaian } \\
(\%)\end{array}$ & Kondisi & Ideal & $\begin{array}{c}\text { Capaian } \\
(\%)\end{array}$ \\
\hline 2011 & 3552 & 5719 & 62.11 & 2594 & 4085 & 63.50 & 1586 & 1634 & 97.06 \\
\hline 2012 & 3763 & 6251 & 60.20 & 2836 & 4465 & 63.52 & 1738 & 1786 & 97.31 \\
\hline 2013 & 4141 & 6965 & 59.45 & 3152 & 4975 & 63.36 & 1923 & 1990 & 96.63 \\
\hline 2014 & 5446 & 15624 & 34.86 & 5631 & 11160 & 50.46 & 4392 & 4464 & 98.39 \\
\hline
\end{tabular}

Sumber: SIMDA BMD 2014 (diolah)

\section{Faktor Internal dan Eksternal Pengelolaan Aset}

Faktor-faktor yang mempengaruhi pengelolaan aset tetap adalah:

1. Kekuatan (Internal)

Kekuatan merupakan potensi yang dapat membawa kemajuan bagi sebuah organisasi. Kekuatan utama yang dimiliki Pemerintah Daerah pada pengelolaan aset adalah tersedianya Sistem Informasi Manajemen Aset/BMD (S1), SDM di tingkat pengambil kebijakan memiliki kompetensi di bidang aset (S2), adanya komitmen Pemerintah Provinsi Banten untuk penyelesaian permasalahan aset (S3), telah dibuat target penyelesaian permasalahan aset dalam bentuk rencana tindak perbaikan (action plan) (S4), adanya peraturan daerah/peraturan gubernur tentang pengelolaan aset (S5), telah ditetapkannya struktur pengelola aset dengan peraturan daerah (S6) dan adanya monitoring dan evaluasi dari Inspektorat Provinsi Banten dalam pengelolaan aset (S7).

2. Kelemahan (Internal)

Kelemahan merupakan faktor yang dapat mengancam pencapaian tujuan. Hasil identifikasi terhadap faktor internal menunjukkan beberapa kelemahan pengelolaan aset adalah kurangnya kompetensi SDM (pegawai) di tingkat pelaksanaan pengelolaan aset yang kurang pelaksana pengelola aset belum melaksanakan tugas sebagaimana mestinya (W2) dan belum adanya sistem insentif untuk pengelola aset yang diberikan secara berkala (W3).

3. Peluang (Eksternal)

Peluang dalam pengelolaan aset tetap berupa adanya pendampingan pengelolaan aset dari BPKP (O1), adanya peraturan perundangan di tingkat pusat yang mengatur dan mendukung pengelolaan aset daerah (O2) dan banyak referensi dan pakar yang berpengalaman dalam aset daerah (O3).

4. Ancaman (Eksternal)

Ancaman dalam pengelolaan aset tetap berupa aset yang diperoleh dari Provinsi Jawa Barat tidak didukung data dan dokumen yang memadai (T1), rekomendasi auditor eksternal (BPK) yang sulit dilaksanakan (T2) dan status aset sebagai barang bukti di pengadilan (T3).

Terhadap faktor-faktor internal dan eksternal dilakukan pemberian bobot dan rating berdasarkan persepsi responden dari SKPD. Penghitungan bobot dan ratingnya dilakukan sebagai alat untuk melihat faktor-faktor mana yang paling memengaruhi pengelolaan aset tetap, sebagai dasar untuk membuat prioritas strategi. Penghitungan tersebut disajikan dalam Internal Factors Analysis Summary (IFAS) pada Tabel 4 dan External Factors Analysis Summary (EFAS) pada Tabel 5. 


\section{Tabel 4 Perhitungan bobot dan rating pada faktor strategi internal}

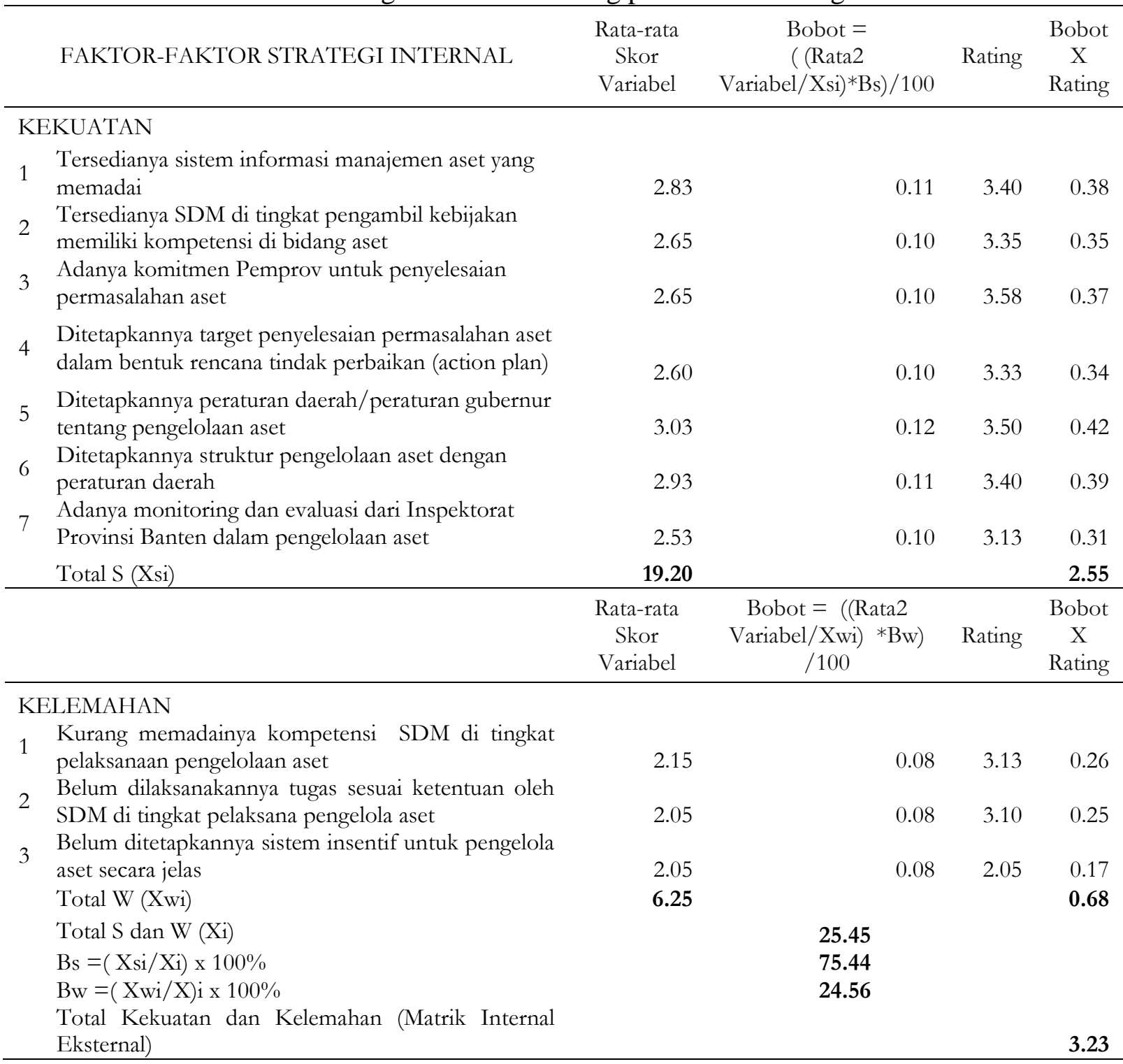

Sumber: Kuesioner SWOT (diolah)

Tabel 4 mengambarkan kekuatan yang dimiliki dengan nilai 2,55 lebih besar dari kelemahan yang dimiliki sebesar 0,68.

Tabel 5 Perhitungan bobot dan rating pada faktor strategi eksternal

\begin{tabular}{|c|c|c|c|c|}
\hline FAKTOR-FAKTOR STRATEGI EKSTERNAL & $\begin{array}{l}\text { Rata-rata } \\
\text { Skor } \\
\text { Variabel }\end{array}$ & $\begin{array}{c}\text { Bobot }= \\
((\text { Rata2 } \\
\text { Variabel/Xoi) } \\
* \text { Bo }) / 100\end{array}$ & Rating & $\begin{array}{c}\text { Bobot X } \\
\text { Rating }\end{array}$ \\
\hline \multicolumn{5}{|l|}{ PELUANG (O) } \\
\hline 1 Adanya pendampingan pengelolaan aset dari BPKP & 2.83 & 0.18 & 3 & 0.62 \\
\hline $\begin{array}{l}2 \text { Adanya peraturan perundangan di tingkat pusat yang } \\
\text { mengatur dan mendukung pengelolaan aset daerah }\end{array}$ & 3.03 & 0.19 & 4 & 0.69 \\
\hline $\begin{array}{l}\text { Tersedianya referensi dan pakar yang berpengalaman } \\
\text { dalam pengelolaan aset daerah }\end{array}$ & 2.48 & 0.16 & 3 & 0.52 \\
\hline \multirow[t]{2}{*}{ Total O (Xoi) } & 8.33 & & & 1.83 \\
\hline & $\begin{array}{l}\text { Rata-rata } \\
\text { Skor } \\
\text { Variabel }\end{array}$ & $\begin{array}{c}\text { Bobot }= \\
((\text { Rata2 } \\
\text { Variabel/Xti) } \\
* \text { Bt }) / 100\end{array}$ & Rating & $\begin{array}{c}\text { Bobot X } \\
\text { Rating }\end{array}$ \\
\hline
\end{tabular}




\section{ANCAMAN (T)}

1 Tidak memadainya data dan dokumen atas aset hibah dari

Provinsi Jawa Barat sebelum pemekaran

$\begin{array}{llll}2.08 & 0.13 & 3 & 0.46 \\ & & & \\ 2.73 & 0.17 & 3 & 0.55 \\ 2.58 & 0.16 & 3 & 0.51 \\ 7.38 & & & \mathbf{1 . 5 2}\end{array}$

2 eksternal (BPK)

3 Adanya status aset sebagai barang bukti di pengadilan

7.38

Total O dan $\mathrm{T}(\mathrm{Xi})$

15.70

$\mathrm{Bo}=(\mathrm{Xoi} / \mathrm{Xi}) \times 100 \%$

53.03

$\mathrm{Bw}=(\mathrm{Xti} / \mathrm{X}) \mathrm{i}$ x $100 \%$

46.97

Total Peluang dan Ancaman (Matrik Internal Eksternal)

Tabel 5 diketahui bahwa peluang yang dimiliki dengan nilai 1,83 lebih besar dari ancaman yang dimiliki sebesar 1,52. Nilai tersebut akan memengaruhi pemilihan strategi pengelolaan aset yang akan lebih memanfaatkan peluang yang dimiliki dibanding dengan menghindari faktor ancaman yang datang dari luar.

\section{Strategi Pengelolaan Aset Tetap}

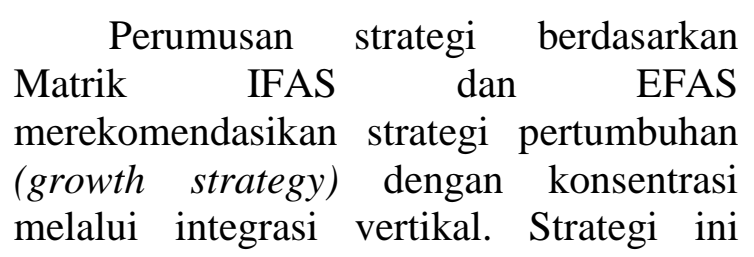

menyatakan pengelolaan aset dikonsentrasikan dengan cara memanfaatkan kekuatan yang dimiliki atau pun dengan memanfaatkan peluang. Hal ini menandakan Provinsi Banten memiliki potensi faktor internal dan eksternal dapat dipadukan untuk memperbaiki pengelolaan aset. Matrik SWOT merupakan pertemuan antara masing-masing faktor internal dan eksternal dimana kedua faktor saling berinteraksi untuk menentukan suatu strategi yang terbaik. Gambaran mengenai perbandingan antar faktor dalam Matrik SWOT dapat dilihat pada Tabel 6.

Tabel 6 Perumusan strategi dengan Matrik SWOT

\begin{tabular}{|c|c|c|c|}
\hline \multicolumn{2}{|c|}{ STRATEGI STRENGTHS-OPPORTUNITY (SO) } & \multicolumn{2}{|c|}{ STRATEGI WEAKNESSES-OPPORTUNITY (WO) } \\
\hline FAKTOR & \begin{tabular}{|c|} 
STRATEGI \\
\end{tabular} & FAKTOR & \begin{tabular}{|c|} 
STRATEGI \\
\end{tabular} \\
\hline \begin{tabular}{|l|}
$\mathrm{S} 1, \mathrm{~S} 3, \mathrm{~S} 5, \mathrm{~S} 6$ \\
$\mathrm{O} 1, \mathrm{O} 2, \mathrm{O} 3$ \\
\end{tabular} & \begin{tabular}{|l|} 
Peningkatan kualitas data aset melalui \\
penggunaan SIMDA Aset/BMD dengan \\
optimal, peningkatan kompetensi SDM \\
pengelola aset, pemberian insentif pada \\
SDM pengelola aset, sosialisasi kebijakan \\
akuntansi dan sistem/prosedur pengelolaan \\
aset pada SDM pengelola aset, dan \\
pelaksanaan pencatatan akuntansi sesuai \\
ketentuan
\end{tabular} & \multirow[t]{3}{*}{$\begin{array}{l}\text { W1,W2, } \\
\text { W3, O1,O2, } \\
\text { O3 }\end{array}$} & \multirow[t]{3}{*}{$\begin{array}{l}\text { Peningkatan kualitas data aset melalui } \\
\text { peningkatan kompetensi SDM pengelola } \\
\text { aset, sosialisasi kebijakan akuntansi dan } \\
\text { sistem/prosedur pengelolaan aset pada } \\
\text { SDM pengelola aset, pelaksanaan } \\
\text { pencatatan akuntansi sesuai ketentuan, } \\
\text { dan pemberian insentif pada SDM } \\
\text { pengelola aset }\end{array}$} \\
\hline $\begin{array}{l}\mathrm{S} 1, \mathrm{~S} 2, \mathrm{~S} 3, \mathrm{~S} 4 \\
\mathrm{~S} 5, \mathrm{~S} 6, \mathrm{~S} 7 \\
\mathrm{O} 1, \mathrm{O} 2, \mathrm{O} 3\end{array}$ & \begin{tabular}{|l|} 
Peningkatan kerjasama antar lembaga \\
melalui pendampingan pengelolaan aset \\
dari BPKP, kerjasama dengan BPN untuk \\
sertifikasi aset tanah
\end{tabular} & & \\
\hline \begin{tabular}{|l|} 
S6,S7,O1, O2 \\
\end{tabular} & \begin{tabular}{|l|} 
Pelaksanaan RTP/action plan melalui \\
peningkatan peran inspektorat dalam \\
pengamanan aset, pelaksanaan sensus dan \\
rekonsiliasi data aset secara rutin
\end{tabular} & & \\
\hline & Bobot X Rating $=4,39$ & & Bobot X Rating $=2,51$ \\
\hline \multicolumn{2}{|c|}{ STRATEGI STRENGTHS-THREATS (ST) } & \multicolumn{2}{|c|}{ STRATEGI WEAKNESSES-THREATS (WT) } \\
\hline FAKTOR & \begin{tabular}{|c|} 
STRATEGI \\
\end{tabular} & FAKTOR & \begin{tabular}{|c|} 
STRATEGI \\
\end{tabular} \\
\hline \begin{tabular}{|l|} 
S3, S4, T1, \\
T2,T3
\end{tabular} & $\begin{array}{l}\text { Peningkatan kerjasama antar lembaga } \\
\text { melaui kerjasama dengan Provinsi Jawa } \\
\text { Barat atas aset hibah, kerjasama dengan } \\
\text { BPN untuk sertifikasi aset Tanah, } \\
\text { koordinasi dengan BPK untuk tindak lanjut } \\
\text { temuan audit, dan kerjasama dengan } \\
\text { penegak hukum terkait status aset sebagai } \\
\text { brang bukti di pengadilan }\end{array}$ & \multirow[t]{2}{*}{$\begin{array}{c}\mathrm{W} 1, \mathrm{~W} 2, \mathrm{~T} 1, \\
\mathrm{~T} 2\end{array}$} & \multirow[t]{2}{*}{$\begin{array}{l}\text { Pelaksanaan RTP/action plan melalui } \\
\text { sensus dan rekonsiliasi data aset secara } \\
\text { rutin, dan pengawalan tindak lanjut atas } \\
\text { temuan audit oleh Inspektorat. }\end{array}$} \\
\hline S4, T2 & $\begin{array}{l}\text { Pelaksanaan RTP/action plan melalui } \\
\text { pengawalan pelaksanaan tindak lanjut } \\
\text { temuan audit oleh Inspektorat }\end{array}$ & & \\
\hline & \begin{tabular}{|r|} 
Bobot X Rating $=4,07$ \\
\end{tabular} & & Bobot X Rating $=2,20$ \\
\hline
\end{tabular}


Berdasarkan perbandingan dalam Matrik SWOT, dapat diketahui bahwa Strategi SO (Strengths-Opportunities) memiliki nilai terbesar, sebagai strategi yang paling diprioritaskan. Jenis strategi yang menjadi prioritas dalam Strategi SO secara berurutan adalah strategi peningkatan kualitas data dengan jumlah pertemuan faktor lima kali, sedangkan strategi peningkatan kerjasama antar lembaga dan strategi pelaksanaan action plan masing-masing dua kali.

Sebagai perbandingan dengan Metode SWOT, pemilihan prioritas strategi menggunakan Metode Analytical
Hierarchy Process (AHP) ditampilkan pada Gambar 2. Metode ini akan melihat persepsi ahli terhadap permasalahan, strategi penyelesaian permasalahan mau pun kendala/permasalahan lain yang masih ditemui didalamnya. Dalam sebuah bentuk hirarki, semua tahapan tersebut dilihat berdasar tingkat/bobot yang paling memengaruhi kinerja pengelolaan aset tetap pada Pemerintah Provinsi Banten. Prioritas pilihan merupakan persepsi ahli bahwa hal tersebut lebih besar/lebih berat dan memerlukan penanganan yang mendesak dibanding dengan pilihan lainnya.

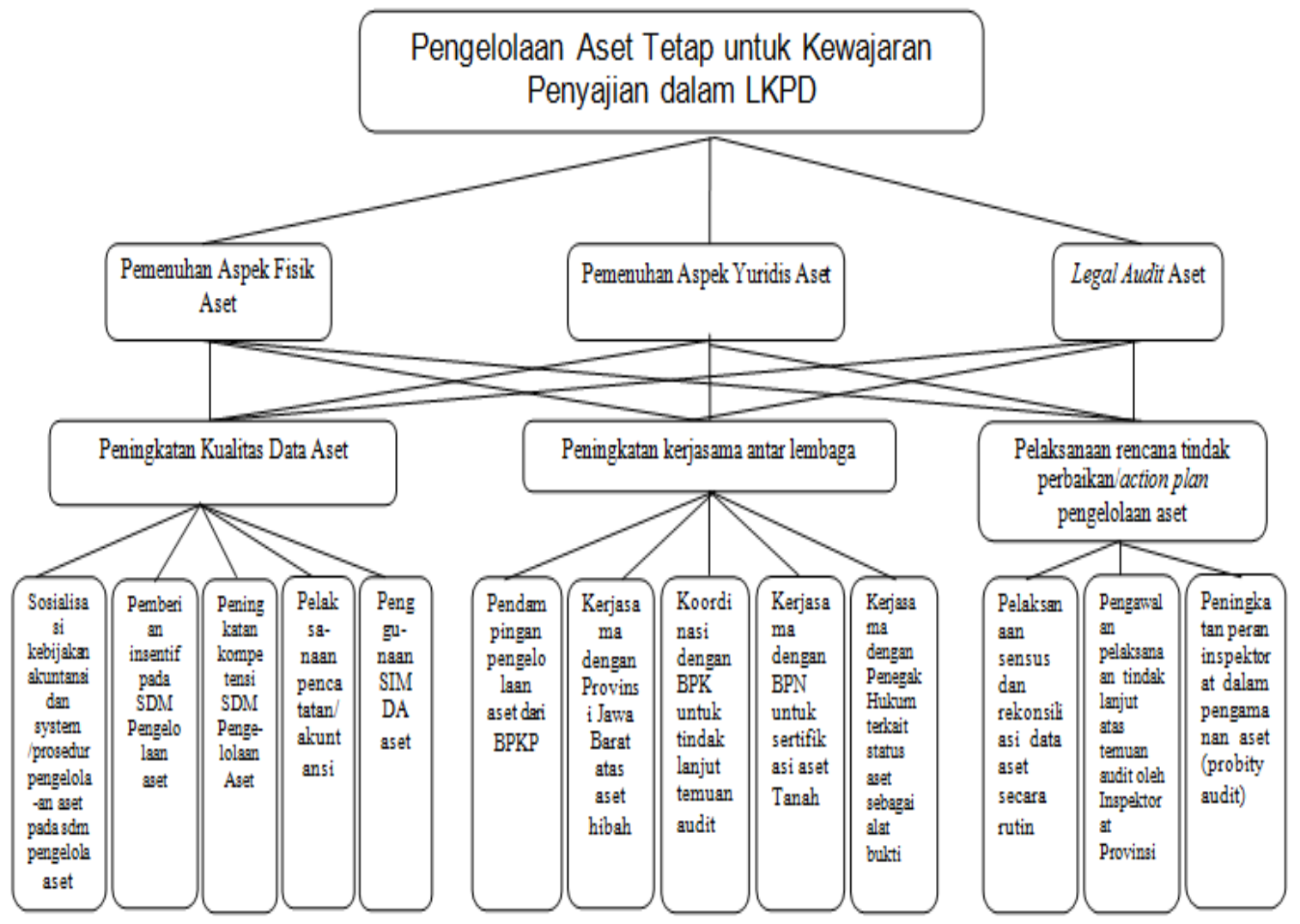

Gambar 2. Struktur Hierarki Pengelolaan Aset Tetap

Hasil pengolahan kuesioner menunjukkan prioritas permasalahan dalam pengelolaan aset tetap terlihat pada Tabel 7. Pada hirarki kedua, persepsi ahli memberi prioritas permasalahan pada pemenuhan kelengkapan aspek fisik. Prioritas kedua pada pemenuhan kelengkapan aspek yuridis dan prioritas ketiga pada aspek legal audit. Artinya permasalahan terbesar yang harus diprioritaskan untuk segera ditangani adalah kelengkapan aspek fisik.

Hasil penilaian atas persepsi ahli pada hirarki ketiga terlihat pada Tabel 8, dimana peningkatan kualitas data aset merupakan strategi prioritas pertama yang dipilih. Semua permasalahan pada hirarki kedua harus segera ditangani dnegan 
Tabel 7 Prioritas permasalahan aset tetap

\begin{tabular}{lll}
\hline Permasalahan & Nilai & Prioritas \\
\hline $\begin{array}{l}\text { Pemenuhan Kelengkapan Aspek } \\
\text { Fisik }\end{array}$ & 0,461 & I \\
$\begin{array}{l}\text { Pemenuhan Kelengkapan Aspek } \\
\text { Yuridis }\end{array}$ & 0,363 & II \\
Aspek Legal Audit & 0,177 & III \\
\hline
\end{tabular}

Sumber: Kuesioner AHP (diolah) strategi peningkatan kualitas data aset. Strategi berikutnya yang dapat dilaksanakan untuk mengatasi permasalahan adalah pelaksanaan RTP/action plan dan peningkatan kerjasama antar lembaga.

Tabel 8 Prioritas strategi pengelolaan aset tetap

\begin{tabular}{|c|c|c|c|c|}
\hline Permasalahan & & Upaya yang Dilakukan & Nilai & Prioritas \\
\hline Pemenuhan & Kelengkapan & Peningkatan kualitas data aset & 0,594 & I \\
\hline \multirow[t]{2}{*}{ Aspek Fisik } & & Pelaksanaan RTP/action plan & 0,295 & II \\
\hline & & Peningkatan kerjasama antar lembaga & 0,111 & III \\
\hline Pemenuhan & Kelengkapan & Peningkatan kualitas data aset & 0,443 & I \\
\hline \multirow[t]{2}{*}{ Aspek Yuridis } & & Pelaksanaan RTP/action plan & 0,290 & II \\
\hline & & Peningkatan kerjasama antar lembaga & 0,267 & III \\
\hline \multirow[t]{3}{*}{ Aspek Legal Audit } & & Peningkatan kualitas data aset & 0,594 & I \\
\hline & & Pelaksanaan RTP/action plan & 0,296 & II \\
\hline & & Peningkatan kerjasama antar lembaga & 0,110 & III \\
\hline
\end{tabular}

Dengan demikian, Metode SWOT dan Metode AHP memprioritaskan strategi pengelolaan aset tetap sesuai prioritas adalah (1) peningkatan kualitas data aset, (2) Pelaksanaan RTP/action plan dan (3) peningkatan kerjasama antar lembaga.

Program dan Implikasi Kebijakan

Pembahasan mengenai tingkat permasalahan dalam pelaksanaan strategi pada hirarki keempat Metode AHP menunjukkan permasalahan pada tahap pelaksanaan strategi berdasar prioritas. Permasalahan tersebut menjadi dasar bagi penyusunan program pendukung strategi. Tingkat/bobot permasalahan yang diberikan para ahli pengelolaan aset daerah menunjukkan bahwa program untuk pelaksanaan strategi tersebut menjadi prioritas untuk dilaksanakan dibanding program lainnya. Masing-masing program tersebut sesuai dengan urutan prioritas berdasarkan bobot permasalahan dan strategi yang dirumuskan dapat dilihat pada Tabel 9.

Penyusunan program berdasarkan persepsi yang digali dari ahli pengelola aset daerah diperoleh pola persepsi antar masing-masing pemenuhan aspek fisik, yuridis dan legal audit sebagai berikut:

1. Strategi peningkatan kualitas data aset

Dalam upaya peningkatan kualitas data aset, para ahli mempersepsikan program yang sama antara pemenuhan aspek yuridis dengan aspek legal audit, dengan urutan program sebagai berikut:

1.1 Peningkatan kompetensi SDM pengelola aset

1.2 Pencatatan akuntansi

1.3 Penggunaan SIMDA

1.4 Pemberian insentif pada SDM Pengelola

1.5 Sosialisasi sistem dan prosedur/kebijakan pengelolaan aset tetap

Pola yang berbeda pada pemenuhan aspek fisik terdapat pada program nomor 1.4 dan 1.5 dengan urutan yang terbalik.

Pola ini menunjukkan bahwa program pada urutan 1.1 sampai 1.3 para ahli bersepakat merupakan program yang harus segera dilaksanakan karena tingkat/bobot nya yang cukup besar. Sedangkan perbedaan pada urutan 1.4 dan 1.5 terlihat bahwa dalam peningkatan kualitas data pada pemenuhan aspek fisik memerlukan sosialisasi sistem dan kebijakan/prosedur kepada SDM 
pengelola barang dibandingkan dengan pemberian insentif. Hal ini dimungkinkan permasalahan dalam peningkatan kualitas data aset terdapat pengelola yang belum memperoleh sosialisasi sistem dan prosedur/kebijakan pengelolaan aset sehingga belum memahami pemenuhan aspek fisik aset.

Tabel 9 Prioritas program pendukung strategi pengelolaan aset

\begin{tabular}{|c|c|c|c|c|}
\hline Permasalahan & Strategi & Program & Nilai & Prioritas \\
\hline \multirow{13}{*}{$\begin{array}{l}\text { Pemenuhan } \\
\text { Kelengkapan } \\
\text { Aspek Fisik }\end{array}$} & \multirow{5}{*}{$\begin{array}{l}\text { Peningkatan } \\
\text { kualitas data } \\
\text { aset }\end{array}$} & Peningkatan kompetensi SDM & 0,422 & $\mathbf{I}$ \\
\hline & & Pelaksanaan pencatatan/akuntansi & 0,241 & II \\
\hline & & Penggunaan SIMDA Aset/BMD & 0,182 & III \\
\hline & & $\begin{array}{l}\text { Sosialisasi Kebijakan akuntansi dan system } \\
\text { pengelolaan aset pada SDM pengelola }\end{array}$ & 0,085 & IV \\
\hline & & Pemberian insentif pada SDM pengelola & 0,070 & V \\
\hline & \multirow{3}{*}{$\begin{array}{l}\text { Pelaksanaa } \\
\text { RTP/action } \\
\text { plan }\end{array}$} & $\begin{array}{l}\text { Peningkatan peran inspektorat dalam } \\
\text { pengamanan aset }\end{array}$ & 0,494 & $\mathbf{I}$ \\
\hline & & Pelaksanaan sensus dan rekonsiliasi data as et & 0,360 & II \\
\hline & & $\begin{array}{l}\text { Pengawalan pelaksanaan tindak lanjut temuan } \\
\text { audit oleh Inspektorat }\end{array}$ & 0,147 & III \\
\hline & \multirow{5}{*}{$\begin{array}{l}\text { Peningkatan } \\
\text { kerjas ama } \\
\text { antar lembaga }\end{array}$} & Kerjas ama dengan BPN untuk sertfikas i tanah & 0,309 & $\mathbf{I}$ \\
\hline & & $\begin{array}{l}\text { Kerjasama dengan Pemerintah Provinsi Jawa } \\
\text { Barat untuk aset hibah }\end{array}$ & 0,229 & II \\
\hline & & $\begin{array}{l}\text { Kerjas ama dengan penegak hukum terkait } \\
\text { status aset sebagai alat bukti di pengadilan }\end{array}$ & 0,166 & III \\
\hline & & $\begin{array}{l}\text { Koordinasi dengan BPK untuk tindak lanjut } \\
\text { temuan aset }\end{array}$ & 0,154 & IV \\
\hline & & Pendampingan pengelolaan aset dari BPKP & 0,143 & V \\
\hline \multirow{13}{*}{$\begin{array}{l}\text { Pemenuhan } \\
\text { Kelengkapan } \\
\text { Aspek Yuridis }\end{array}$} & \multirow{5}{*}{$\begin{array}{l}\text { Peningkatan } \\
\text { kualitas data } \\
\text { aset }\end{array}$} & Peningkatan kompetensi SDM & 0,331 & $\mathbf{I}$ \\
\hline & & Pelaksanaan pencatatan/akuntansi & 0,292 & II \\
\hline & & Penggunaan SIMDA Aset/BMD & 0,196 & III \\
\hline & & Pemberian insentif pada SDM pengelola & 0,103 & IV \\
\hline & & $\begin{array}{l}\text { Sosialisasi Kebijakan akuntansi dan system } \\
\text { pengelolaan aset pada SDM pengelola }\end{array}$ & 0,078 & V \\
\hline & \multirow{3}{*}{$\begin{array}{l}\text { Pelaksanaa } \\
\text { RTP/action } \\
\text { Plan }\end{array}$} & Pelaksanaan sensus dan rekonsiliasi data aset & 0,436 & $\mathbf{I}$ \\
\hline & & $\begin{array}{l}\text { Peningkatan peran inspektorat dalam } \\
\text { pengamanan aset }\end{array}$ & 0,369 & II \\
\hline & & $\begin{array}{l}\text { Pengawalan pelaksanaan tindak lanjut temuan } \\
\text { audit oleh Inspektorat }\end{array}$ & 0,195 & III \\
\hline & \multirow{5}{*}{$\begin{array}{l}\text { Peningkatan } \\
\text { kerjas ama } \\
\text { antar lembaga }\end{array}$} & Kerjas ama dengan BPN untuk sertfikasi tanah & 0,336 & $\mathbf{I}$ \\
\hline & & $\begin{array}{l}\text { Kerjasama dengan Pemerintah Provinsi Jawa } \\
\text { Barat untukaset hibah }\end{array}$ & 0,205 & II \\
\hline & & $\begin{array}{l}\text { Kerjas ama dengan penegak hukum terkait } \\
\text { status aset sebagai alat bukti di pengadilan }\end{array}$ & 0,165 & III \\
\hline & & $\begin{array}{l}\text { Koordinasi dengan BPK untuk tindak lanjut } \\
\text { temuan aset }\end{array}$ & 0,160 & IV \\
\hline & & Pendampingan pengelolaan aset dari BPKP & 0,133 & V \\
\hline \multirow{13}{*}{$\begin{array}{l}\text { Aspek } \\
\text { Audit }\end{array}$} & \multirow{5}{*}{$\begin{array}{l}\text { Peningkatan } \\
\text { kualitas data } \\
\text { aset }\end{array}$} & Peningkatan kompetensi SDM & 0,382 & $\mathbf{I}$ \\
\hline & & Pelaksanaan pencatatan/akuntansi & 0,266 & II \\
\hline & & Penggunaan SIMDA Aset/BMD & 0,180 & III \\
\hline & & Pemberian insentif pada SDM pengelola & 0,105 & IV \\
\hline & & $\begin{array}{l}\text { Sosialisasi Kebijakan akuntansi dan system } \\
\text { pengelolaan aset pada SDM pengelola }\end{array}$ & 0,066 & V \\
\hline & \multirow{3}{*}{$\begin{array}{l}\text { Pelaksanaa } \\
\text { RTP/action } \\
\text { plan }\end{array}$} & Pelaksanaan sensus dan rekonsiliasi data aset & 0,435 & $\mathbf{I}$ \\
\hline & & $\begin{array}{l}\text { Peningkatan peran inspektorat dalam } \\
\text { pengamanan aset }\end{array}$ & 0,371 & II \\
\hline & & $\begin{array}{l}\text { Pengawalan pelaksanaan tindak lanjut temuan } \\
\text { audit oleh Inspektorat }\end{array}$ & 0,193 & III \\
\hline & \multirow{5}{*}{$\begin{array}{l}\text { Peningkatan } \\
\text { kerjas ama } \\
\text { antar lembaga }\end{array}$} & Kerjas ama dengan BPN untuk sertfikas i tanah & 0,314 & $\mathbf{I}$ \\
\hline & & $\begin{array}{l}\text { Kerjas ama dengan penegak hukum terkait } \\
\text { status aset sebagai alat bukti di pengadilan }\end{array}$ & 0,221 & II \\
\hline & & $\begin{array}{l}\text { Kerjasama dengan Pemerintah Provinsi Jawa } \\
\text { Barat untukaset hibah }\end{array}$ & 0,187 & III \\
\hline & & $\begin{array}{l}\text { Koordinasi dengan BPK untuk tindak lanjut } \\
\text { temuan aset }\end{array}$ & 0,150 & IV \\
\hline & & Pendampingan pengelolaan aset dari BPKP & 0,127 & V \\
\hline
\end{tabular}

2. Startegi pelaksanaan RTP/action plan Dalam startegi pelaksanaan RTP/action plan, para ahli mempersepsikan program yang sama antara pemenuhan aspek yuridis dengan aspek legal audit, dengan urutan program sebagai berikut: 
2.1 Pelaksanaan sensus dan rekonsiliasi data aset

2.2 Peningkatan peran Inspektorat dalam pengamanan aset

2.3 Pengawalan pelaksanaan tindak lanjut temuan audit oleh Inspektorat

Pola yang berbeda pada pemenuhan aspek fisik terdapat pada program nomor 2.1 dan 2.2 dengan urutan yang terbalik.

Pola ini menunjukkan bahwa pada program 2.3 para ahli bersepakat merupakan program yang tidak prioritas untuk dilaksanakan karena tingkat/bobot nya yang rendah. Sedangkan perbedaan pada urutan 2.1 dan 2.2 terlihat bahwa dalam strategi pelaksanaan RTP/action plan pada pemenuhan aspek fisik memerlukan peningkatan peran inspektorat dalam pengamanan aset dibandingkan dengan pelaksanaan sensus dan rekonsiliasi data aset. Hal ini dimungkinkan persepsi atas kurangnya peran inspektorat dalam pengamanan aspek fisik aset dibanding dengan aspek yuridis dan legal audit.

3. Strategi peningkatan kerjasama antar lembaga

Dalam strategi peningkatan kerjasama antar lembaga, para ahli mempersepsikan program yang sama antara pemenuhan aspek fisik dengan aspek yuridis, dengan urutan program sebagai berikut:

3.1 Kerjasama dengan BPN untuk sertifikasi aset Tanah

3.2 Kerjasama dengan Pemerintah Provinsi Jawa Barat atas aset hibah

3.3 Kerjasama dengan aparat penegak hukum terkait status aset sebagai alat bukti

3.4 Koordinasi dengan BPK untuk tindak lanjut temuan audit

3.5 Pendampingan pengelolaan aset dari BPKP

Pola yang berbeda pada pemenuhan aspek legal audit terdapat pada program nomor 3.2 dan 3.3 dengan urutan yang terbalik.
Pola ini menunjukkan bahwa tingkat/bobot permasalahan pada urutan 3.1, 3.4 dan 3.5, para ahli bersepakat merupakan program dengan prioritas yang sama, yaitu prioritas program tertinggi pada 3.1 dan prioritas program terrendah pada 3.4 dan 3.5. Sedangkan perbedaan pada urutan 3.2 dan 3.3 terlihat bahwa dalam peningkatan kerjasama antar lembaga pada pemenuhan aspek legal audit lebih memprioritaskan kerjasama dengan aparat penegak hukum dibandingkan dengan kerjasama dengan Pemerintah Provinsi Jawa Barat. Hal ini dimungkinkan karena persepsi ahli bahwa kerjasama dengan aparat penegak hukum merupakan program yang lebih prioritas untuk ditangani dibanding dengan permasalahan kerjasama dengan Provinsi Jawa Barat.

\section{SIMPULAN DAN SARAN Simpulan}

Sistem pengelolaan aset tetap belum diimplementasikan secara optimal. Hal ini mempengaruhi kinerja pengelolaan aset. Indek kinerja tanah terrendah pada pemenuhan aspek yuridis, sedangkan pada Gedung/Bangunan indek terrendah pada pemenuhan aspek fisik. Sedangkan menurut persepsi para ahli pengelolaan aset permasalahan terbesar menyangkut aspek fisik.

Faktor internal dan eksternal yang paling berpengaruh dalam pengelolaan aset tetap secara berurutan adalah kekuatan, peluang, ancaman dan kelemahan. Namun secara umum pengelolaan aset tetap memiliki peluang yang sangat tinggi dan kekuatan yang sangat besar untuk dapat dimanfaatkan bagi perbaikan pengelolaan aset tetap.

Strategi pertumbuhan merupakan strategi yang sesuai untuk kondisi pengelolaan aset tetap. Sedangkan simpulan strategi berdasarkan Matrik SWOT dan Metode AHP secara berurutan adalah (1) strategi peningkatan kualitas 
data aset, (2) strategi pelaksanaan RTP/action plan dan (3) strategi peningkatan kerjasama antar lembaga.

\section{Saran}

Strategi pengelolaan aset tetap sesuai prioritas telah didapatkan. Hasil dari penelitian juga merekomendasikan usulan program untuk mendukung strategi. Saran bagi pengelolaan aset tetap pada Pemerintah Provinsi Banten adalah agar pelaksanaan strategi dan program yang telah direkomendasikan dijalankan sesuai dengan urutan prioritasnya.

Penelitian selanjutnya diharapkan membahas pemenuhan aspek fisik, yuridis dan legal audit pada aset tetap selain tanah dan gedung/bangunan, seperti jalan/jaringan/jembatan.

\section{DAFTAR PUSTAKA}

Azhar I, Darwanis, Abdullah S. 2011. Pengaruh Kualitas Aparatur Daerah, Regulasi, dan Sistem Informasi terhadap Manajemen Aset. Jurnal. Banda Aceh (ID): Univesitas Syiahkuala.

[BPK] Badan Pemeriksa Keuangan. 20112014. Laporan Hasil Audit BPK atas Laporan Keuangan Pemerintah Provinsi Banten Tahun 2011, 2012, 2013 dan 2014. Jakarta (ID): BPK.

Homer Y. 2014. Inventarisasi dan Legalisasi Aset Tetap Tanah dan Bangunan Milik Pemerintah Daerah Provinsi Papua di Kota Jayapura Tahun 2012. Tesis. Yogyakarta (ID): Universitas Gajah Mada.

Kementerian Dalam Negeri. 2007. Peraturan Menteri Dalam Negeri Nomor 17 Tahun 2007 tentang Pedoman Teknis Pengelolaan Barang Milik Daerah. Jakarta (ID): Kementerian Dalam Negeri.

M.S. Abdelhamid, I. Beshara, M. Ghoneim. 2014. Strategic aset management: Assessment tool for educational building in Egypt, Housing and Building National Research Centre (HBRC). Jurnal. Kairo (EG): Cairo University.
Pekei B, Hadiwidjojo Dj, Djumahir, Sumiati. 2014.The Effectiveness Of Local Aset Management (A Study On The Government Of Jayapura). Jurnal. Malang (ID): Univesitas Brawijaya.

Pemerintah Republik Indonesia. 2010. Peraturan Pemerintah Nomor 71 Tahun 2010 tentang Standar Akuntansi Pemerintah Laporan keuangan. Jakarta (ID): Sekretariat Negara.

Pemerintah Provinsi Banten. 2008. Peraturan Daerah Nomor 17 Tahun 2008 tentang Pengelolaan Barang Milik Daerah (BMD). Serang (ID): Pemerintah Provinsi Banten.

Siregar DD. 2004. Manajemen Aset, Strategi Penataan Konsep Pembangunan Berkelanjutan secara Nasional dalam Konteks Kepala Daerah sebagai CEO's pada Era Globalisasi dan Otonomi Daerah. Jakarta (ID): PT Gramedia. 